\title{
Jamur Mikoriza Vesikular Arbuskular (MVA) Pada Tiga Jenis Tanah Rhizosfer Tumbuhan Lakum (Cayratia trifolia (L.) Domin)
}

\author{
Tri Oktarini Adiaty ${ }^{1}$, Riza Linda ${ }^{1}$, Mukarlina ${ }^{1}$ \\ ${ }^{1}$ Program Studi Biologi,Fakultas MIPA, Universitas Tanjungpura,Jl. Prof. Dr.H. Hadari Nawawi, Pontianak, \\ Email korespondensi: trioktariniadiaty1382@gmail.com
}

\begin{abstract}
Abstrack
The lakum plant (Cayratia trifolia (L.) Domin) is a wild plant so it is easily found in various types of soil, such as alluvial soil, ultisol soil and soil with salinity (saline soil). The ability of the lakum plant $(C$. trifolia) to grow on alluvial soil, ultisol soil, and saline soils is presumably cause by a role of Vesicular Arbuscular Mycorrhizal (VAM) fungi. This research aims to find out about VAM fungi in the rhizosphere of the lakum plant (C. trifolia) and the rate of VAM fungal infection in three types of rhizosphere soil of the lakum plant. This research was conducted for three months, starting from January to May 2018 at the Microbiology Laboratory of the Faculty of Mathematics and Natural Sciences of Tanjungpura University. The research procedure included several stages, namely sampling, isolation of spores by a combination of wet filter pouring technique, identification and characterization, and coloring and making root preparations with coloring method. Based on the results of the research, the spores of the VAM fungi found in alluvial soil consisted of the genera Acaulospora, Archaeospora, Glomus and Paraglomus. The spores of the genus of VAM fungi found on the saline soil were only the genus Glomus. The spores of the genus of VAM fungi found on ultisol soil consisted of the genera Acaulospora, Glomus and Paraglomus. The results of observations show that VAM fungal infection in alluvial soil was $25 \%$ (low), in saline soil $50.6 \%$ (high) and ultisol soil 53\% (high).
\end{abstract}

Keywords: VAM, Alluvial, saline, ultisol soil, Cayratia trifolia

\section{PENDAHULUAN}

Tumbuhan lakum (Cayratia trifolia (L.) Domin) merupakan tumbuhan herba yang digolongkan ke dalam anggota Famili Vitaceae. Tumbuhan ini memiliki banyak potensi, yang dimanfaatkan oleh masyarakat. Beberapa penelitian melaporkan daun tumbuhan lakum memiliki kemampuan sebagai surfaktan alami (Lisnawati 2014 dalam Putri, 2015). Batang tumbuhan lakum dapat dimanfaatkan sebagai tali temali, dianyam dan dijadikan alat penangkap ikan (Ayyanar \& Lgnacimuthu, 2010). Akar tumbuhan lakum dapat digunakan untuk menyembuhkan penyakit anemia (Khare, 2007 dalam Kumar et al., 2011) dan dapat dimanfaatkan sebagai sebagai anti racun ular (Choudhary et al., 2007). Buah lakum dapat diolah menjadi produk makanan dan minuman (Prasetyo et al,. 2016) dan memiliki potensi sebagai obat kanker (Kumar et al., 2011).

Tumbuhan lakum (C. trifolia) termasuk tumbuhan liar sehingga mudah ditemukan di berbagai jenis tanah, seperti tanah aluvial, tanah podsolik merah kuning (PMK) dan tanah yang menggandung kadar garam (tanah salin). Tanah PMK dan Aluvial banyak ditemukan di daerah perkebunan sedangkan tanah salin ditemukan di kawasan mangrove. Tanah aluvial dan tanah podsolik merah kuning (PMK) memiliki karakteristik tanah asam nilai pH berkisar 4-6 (Kaleka, 2013). Keadaaan tanah yang asam menjadikan kandungan unsur hara yang terdapat didalam tanah tersebut tidak tersedia, berakibat pada pertumbuhan tanaman yang tidak optimal. Kekurangan ketersedian hara tanah juga terjadi pada tanah salin, sehingga berakibat tanaman tidak dapat tumbuh secara optimal. Kristiono et.al (2013) menyatakan tanah yang memiliki kadar garam (salin) mengakibatkan tanaman mengalami tekanan osmotik dan kurangnya ketersediaan unsur hara.

Kemampuan tumbuhan lakum (C. trifolia) tumbuh pada tanah aluvial, tanah PMK, dan tanah salin tersebut diduga adanya peran jamur Mikoriza Vesikular Arbuskular (MVA). Jamur MVA adalah bentuk simbiosis mutualistik antara jamur dan akar tumbuhan. Jamur MVA berperan dalam meningkatkan penyerapan unsur hara dan nutrisi pada tanaman dari dalam tanah dan diketahui meningkatkan ketahanan tanaman terhadap patogen (Kartika, 2001).

Beberapa tumbuhan yang mampu tumbuh di kondisi tanah aluvial, PMK dan salin dikarenakan 
adanya peran dari jamur MVA. Saputra et al., (2015) tanah aluvial dan PMK pada rhizosfer tanaman Pisang Nipah (M. paradisiaca L. var. nipah) daerah Kabupaten Pontianak ditemukan genus MVA Acaulospora, Archaeospora, Gigaspora Glomus dan Paraglomus dengan masing-masing presentase infeksi akar sebesar $53 \%$ dan $57 \%$ dengan kategori tingkat infeksi tinggi. Hasil penelitian Wanda et al., (2015) melaporkan keberadaan mikoriza pada tanah salin, dengan tingkat infeksi akar tanaman tertinggi pada Ipomoea sp. sebesar 93\% (sangat tinggi).

Kondisi lingkungan, jenis tanah dan jenis tanaman yang bervariasi menyebabkan penyebaran dan keanekargaman jamur MVA yang bervariasi (Widyaningrum et al., 2016). Sampai saat ini informasi jamur MVA yang berasosiasi pada rhizosfer tumbuhan lakum (C. trifolia) belum pernah dilakukan. Berdasarkan uraian tersebut, maka perlu dilakukan penelitian untuk mengetahui jenis jamur MVA pada tiga jenis tanah rhizosfer tumbuhan lakum (Cayratia trifolia (L.) Domin) di Kecamatan Mempawah Timur, Kabupaten Mempawah.

\section{BAHAN DAN METODE}

\section{Waktu dan Tempat Penelitian}

Penelitian dilakukan selama 5 bulan dari bulan Januari 2018 sampai bulan Mei 2018. Lokasi pengambilan sampel tanah dilakukan di tiga desa Kec. Mempawah Timur yaitu Desa Pasir Palembang (tanah aluvial), Desa Bakau Kecil (tanah salin) dan Desa Antibar (tanah PMK) (Gambar 1). Isolasi dan identifikasi jamur MVA dilakukan di Laboratorium Mikrobiologi Fakultas Matematika dan Ilmu Pengetahuan Alam. Analisis kandungan kimia tanah dilakukan di Laboratorium Kimia dan Kesuburan Tanah Fakultas Pertanian Universitas Tanjungpura Pontianak.

\section{Alat dan Bahan}

Peralatan yang digunakan dalam penelitian ini adalah alat tulis, botol film, cangkul, cawan petri, gelas beker, gelas obyek, gelas ukur, General Position Satelite (GPS), hotplate, kamera digital, kertas label, kuas, mikroskop stereo, neraca analitik, pipet tetes, plastik, pinset, saringan bertingkat, sarung tangan,sekop kecil, satelit, sentrifuse, soiltester dan termometer.

Bahan yang digunakan adalah akuades, akar tanaman lakum, larutan glukosa $60 \%$, larutan $\mathrm{HCl}$ $2 \%$, larutan $\mathrm{H}_{2} \mathrm{O}_{2} 30 \%$, larutan $\mathrm{KOH} 10 \%$, larutan laktogliserol, larutan melzer, larutan $\mathrm{NaClO}$ $5,25 \%$, larutan trypan blue, sampel tanah aluvial, salin dan gambut.

\section{Prosedur Kerja}

Pengambilan sample

Pengambilan sampel tanah dan akar dilakukan di tiga lokasi dengan jenis tanah yang berbeda. Lokasi Pertama Desa Antibar (Tanah PMK), lokasi ke Dua Desa Pasir Palembang (Tanah Aluvial) dan lokasi ke Tiga Desa Bakau Kecil (Tanah Salin). Pada setiap lokasi ditentukan tiga titik pengambilan sampel secara acak. Setiap titik yang ditentukan berada disekitar perakaran tumbuhan lakum dengan kedalaman 0-20 cm. Sampel tanah yang diambil pada setiap tiitik kemudian dikopositkan. Sampel tanah yang telah dikompositkan dari ke tiga titik pengambilan tersebut diambil sebanyak 500 g. Sampel tersebut kemudin dipisahkan menjadi $300 \mathrm{~g}$ tanah untuk isolasi spora dan $200 \mathrm{~g}$ tanah untuk analisis kandungan tanah. Kemudian dilakukan pengulangan sebanyak 3 kali pada setiap jenis tanah, sehingga jumlah keseluruhan sampel sebanyak 9 sampel akar dan 9 sampel tanah (Warouw dan Reynold, 2010 dalam Saputra et al.,2015)

\section{Pengukuran Faktor Lingkungan}

Parameter faktor lingkungan yang diukur yaitu $\mathrm{pH}$ tanah, kadar $\mathrm{N}(\%), \mathrm{K}\left(\mathrm{cmol}(+) \mathrm{Kg}^{-1}\right)$ dan $\mathrm{P}$ (ppm)

\section{Isolasi Spora}

Isolasi spora jamur MVA dilakukan dengan menggunakan teknik tuang saring basah (Pacioni, 1992 dalam Triningsih, 2008) dengan tahapan sebagai berikut:

1. Sampel tanah ditimbang seberat $100 \mathrm{~g}$ per sampel, kemudian dilarutkan dalam $300 \mathrm{ml}$ akuades dan diaduk sampai homogen.

2. Kemudian sampel tanah disaring menggunakan saringan bertingkat dengan ukuran $600 \mu \mathrm{m}$ (saringan kasar);300 $\mu \mathrm{m}$ (saringan sedang); $106 \mu \mathrm{m}$ (saringan sedang) dan $63 \mu \mathrm{m}$ (saringan halus).

3. Tanah yang tersisa pada saringan $300 \mu \mathrm{m}$ (saringan sedang); $106 \mu \mathrm{m}$ (saringan sedang) dan $63 \mu \mathrm{m}$ (saringan halus) dikumpulkan dan dimasukan ke dalam botol dan diamati dibawah mikroskop untuk dihitung jumlah spora.

\section{Identifikasi Spora}

Identifikasi dan karakterisasi jenis jamur MVA dibedakan berdasarkan ciri-ciri umum seperti bentuk spora, warna spora, jumlah dinding spora, reaksi spora ketika diberi larutan melzer. Deskripsi karakterisasi spora jamur MVA dilakukan dengan menggunakan buku berjudul Manual for identification ov VA Mycorryzal Fungi ( Schenck dan Perez, 1990) dan sumber internet 
dari International Culture Collection of Vesicular Arbuscular Mycorrhizal Fungi (INVAM, 2017).

\section{Pembuatan dan Pewarnaan Preparat akar}

Akar dicuci sampai bersih dan diletakkan ke dalam cawan petri, akar diberi larutan $\mathrm{NaClO}$ $5,25 \%$ selama \pm 5 menit, Lalu dibilas dengan akuades, setelah itu akar diberi dengan larutan $\mathrm{KOH} 10 \%$ yang dipanaskan pada suhu $60^{\circ} \mathrm{C}$ selama \pm 15 menit, lalu dibilas dengan akuades. Setelah itu akar diberi dengan larutan $\mathrm{H}_{2} \mathrm{O}_{2} 30 \%$ sampai terlihat putih bening. Selanjutnya akar diberi larutan HCL 2\% \pm 5 menit. Setelah itu akar diwarnai dengan larutan trypan blue selama \pm 10 menit, dan dibilas dengan akuades. Kemudian akar diberi dengan lato gliserol selama \pm 5 menit. Akar dipotong $\pm 1 \mathrm{~cm}$ sebanyak 30 buah dan diamati dibawah mikroskop.

\section{Perhitungan Akar yang Terinfeksi Jamur MVA}

Potongan akar yang telah diwarnai diambil secara acak dan disusun pada gelas objek, kemudian setiap potong akar diamati di bawah mikroskop untuk melihat struktur jamur MVA adalah ditemukannya struktur berupa hifa, spora, vesikula dan arbuskula. Presentase akar yang terinfeksi dihitung berdasarkan rumus :

$\%$ infeksi akar $=\frac{\sum \text { akar yang terinfeksi }}{\sum \text { akar yang diamati }} \times 100 \%$

Menurut Setiadi (2001), tingkat persentase infeksi jamur MVA pada akar ditentukan berdasarkan kelas infeksi yaitu:

1. Kelas 1 infeksi akar berada pada $0 \%$ $5 \%$

(sangat rendah).

2. Kelas 2 infeksi akar berada pada $6 \%-25 \%$ (rendah)

3. Kelas 3 infeksi akar berada pada $26 \%-50 \%$ (sedang)

4. Kelas 4 infeksi akar berada pada $51 \%-75 \%$ (tinggi)

5. Kelas 5 infeksi akar berada pada $76 \%-100 \%$ (sangat tinggi)

\section{HASIL DAN PEMBAHASAN}

\section{Hasil}

\section{Karakteristik Spora Genus Jamur MVA}

Hasil isolasi dan identifikasi spora Genus jamur MVA pada tiga jenis tanah rhizosfer tumbuhan lakum (C. trifolia) di Kecamatan Mempawah Timur ditemukan 4 spora genus jamur MVA yaitu genus Acaulospora, Archaeospora, Glomus dan Paraglomus.

Karakteristik genus spora jamur MVA yang ditemukan pada rhizosfer tumbuhan lakum memiliki perbedaan karakter morfologi. Perbedaan morfologi tersebut dapat dilihat dari bentuk, warna, jumlah dinding lapisan dan reaksi spora saat diberikan larutan melzer. Karakteristik tersebut dapat dilihat pada Tabel 1 .

Tabel 1.Karakteristik spora genus jamur MVA pada tiga jenis tanah rhizosfer tumbuhan lakum (C. trifolia)

\begin{tabular}{ccccc}
\hline & \multicolumn{4}{c}{ Karakterisik Spora } \\
\cline { 2 - 5 } $\begin{array}{c}\text { Genus Jamur } \\
\text { MVA }\end{array}$ & Bentuk & $\begin{array}{c}\text { Warna } \\
\text { sebelum } \\
\text { diberi } \\
\text { larutan } \\
\text { Melzer }\end{array}$ & $\begin{array}{c}\text { Warna } \\
\text { sebelum } \\
\text { diberi } \\
\text { larutan } \\
\text { Melzer }\end{array}$ & $\begin{array}{c}\text { Jumlah } \\
\text { dinding }\end{array}$ \\
\hline Acaulospora & Bulat & Kuning & Orange & 3 \\
\hline Archaeospora & $\begin{array}{c}\text { Bulat } \\
\text { Telur }\end{array}$ & Bening & Bening & 2 \\
\hline Glomus & Bulat & Orange & Orange & 2 \\
\hline Paraglomus & $\begin{array}{c}\text { Bulat } \\
\text { Telur }\end{array}$ & Bening & Bening & 1 \\
\hline
\end{tabular}

Jumlah Spora Genus Jamur Mikoriza Vesikular Arbuskular (MVA)

Jumlah spora genus jamur MVA yang ditemukankan pada tiga jenis tanah rhizosfer tumbuhan lakum (C. trifolia)berbeda-beda. Jumlah spora genus jamur MVA pada tiga jenis tanah dapat dilihat pada Tabel. 2

Tabel 2. Jumlah spora genus jamur MVA pada tiga jenis tanah rhizosfer tumbuhan lakum (C. trifolia)

\begin{tabular}{cccc}
\hline \multirow{2}{*}{$\begin{array}{c}\text { Genus Jamur } \\
\text { MVA }\end{array}$} & \multicolumn{3}{c}{ Jumlah Spora pada Tiga Jenis Tanah } \\
\cline { 2 - 4 } & Aluvial & Salin & PMK \\
\hline Acaulospora & 1 & - & 1 \\
\hline Archaeospora & 1 & - & - \\
\hline Glomus & 96 & 127 & 148 \\
\hline Paraglomus & 2 & - & 1 \\
\hline Jumlah & 100 & 127 & 150 \\
\hline
\end{tabular}

Berdasarkan Tabel 2 diketahui bahwa jenis tanah yang memiliki jumlah spora jamur MVA yang terbanyak adalah tanah PMK dengan jumlah spora sebanyak 150 spora. Pada Tanah PMK ditemukan Genus Acaulospora, Glomus, dan Paraglomus. Jenis tanah yang memiliki jumlah paling sedikit terdapat pada tanah aluvial dengan jumlah spora sebanyak 100 spora. Spora Genus jamur MVA yang ditemukan pada tanah aluvial terdiri atas genus Acaulospora, Archaeospora, Glomus dan Paraglomus. Tanah Salin memiliki jumlah spora sebanyak 127 genus spora terdiri atas genus Glomus. Genus spora yang mempunyai jumlah terbesar dari ketiga jenis tanah yang diamati adalah spora genus Glomus. Genus spora MVA yang memiliki jumlah spora terendah adalah genus Archaeospora dan hanya ditemukan pada tanah aluvial. Spora Acaulospora dan 
Paraglomus sama-sama ditemukan pada 2 jenis tanah yaitu tanah aluvial dan PMK.

Tingkat infeksi jamur MVA pada perakaran tumbuhan lakum (C. trifolia) dapat menginformasikan kondisi tumbuhan secara langsung. Tingkat infeksi jamur MVA pada perakaran tumbuhan lakum (C. trifolia) ditampilkan ke dalam Tabel 3.

Tabel 3. Persentase infeksi jamur MVA pada akar tumbuhan lakum (C. Trifolia)

\begin{tabular}{ccc}
\hline Jenis Tanah & Rerata $(\%)$ & Kelas Infeksi \\
\hline Aluvial & 25 & Rendah \\
\hline Salin & 51 & Tinggi \\
\hline PMK & 53 & Tinggi \\
\hline
\end{tabular}

Berdasarkan tabel .3 tingkat infeksi jamur MVA pada akar tumbuhan lakum (C. trifolia) yang memiliki tingkat infeksi kategori tinggi terdapat pada tanah salin dan tanah PMK, masing-masing memiliki nilai yaitu $51 \%$ dan 53\%. Tingkat infeksi rerata kategori sedang terdapat pada jenis tanah aluvial dengan besaran nilai $25 \%$.

Pertumbuhan dan perkembangan jamur MVA sangat dipengaruhi oleh adanya faktor lingkungan. Hasil pengukuran faktor lingkungan yang dilakukan pada tiga tanah tertera pada Tabel. 4 .

Tabel 4. Pengukuran faktor lingkungan tiga jenis tanah rhizosfer tumbuhan lakum (C.trifolia)

\begin{tabular}{lccc}
\hline \multirow{2}{*}{ Parameter } & \multicolumn{3}{c}{ Jenis Tanah } \\
\cline { 2 - 4 } & Aluvial & Salin & PMK \\
\hline pH & 5,58 & 5,58 & 4,32 \\
Salinitas(ppt) & - & 1,6 & - \\
N-total(\%) & 0,64 & 0,32 & 0,11 \\
P-tersedia(ppm) & 67,65 & 20,34 & 11,32 \\
K & 0,78 & 1,44 & 0,13 \\
Tekstur & & & \\
- Pasir & 31,94 & 0,36 & 28,38 \\
- Debu & 37,46 & 63,35 & 39,07 \\
- Liat & 37,46 & 36,29 & 32,55 \\
\hline Keterangan : & & & \\
\multicolumn{1}{c}{ N: Nitrogen } & & & \\
$\quad$ P: Fosfor & & & \\
\multicolumn{1}{l}{ K: Kalium } & & &
\end{tabular}

Berdasarkan hasil pengukuran faktor lingkungan dapat diketahui tanah aluvial dan tanah salin memiliki $\mathrm{pH}$ yang sama yaitu 5,58 dan $\mathrm{Ph}$ terendah tanah PMK yaitu 4,32. Kandungan unsur hara tertinggi terdapat pada tanah aluvial $\mathrm{N}$-total $0,64 \%$, P-tersedia 67,65 ppm dan $\mathrm{K}$ 0,78, Kandungan unsur hara terendah ada pada tanah PMK, kandungan N-total 0,11 \%, P-tersedia $11,32 \%$ dan K 0,13 . Salinitas pada tanah salin adalah $16 \%$.

\section{Pembahasan}

Hasil penelitian menunjukan bahwa pada tiga jenis tanah rhizosfer tumbuhan lakum (C.trifolia L. (Domin) empat genus spora jamur MVA yaitu, Acaulospora, Archaeospora, Glomus dan Paraglomus. Hasil penelitian ini menunjukkan bahwa empat genus tersebut dapat beradaptasi dan bersimbiosis dengan perakaran tumbuhan lakum. Spora genus jamur MVA yang ditemukan mempunyai karakteristik yang berbeda dapat dilihat pada tabel 1. Karakteristik spora genus jamur MVA tersebut adalah sebagai berikut:

Genus Acaulospora yang ditemukan pada umumnya memiliki karakteristik berbentuk bulat dan bulat telur. Jumlah dinding spora yang terihat sebanyak 3 lapisan. Permukaan spora berwarna kuning namun setelah diteteskan larutan melzer permukaan spora berubah warna menjadi warna orange. Karakteristik genus spora Acaulospora yang ditemukan memiliki kesamaan dengan karakteristik spora menurut INVAM (2017) yaitu genus spora Acaulospora mempunyai bentuk bulat, bulat telur, elips dan oval, warna spora merah, kuning dan jingga, terjadi perubahan warna spora ketika ditetesi melzer dan jumlah dinding spora sebanyak 2 sampai 3 lapisan.

Genus Archaeospora yang ditemukan memiliki karakteristik berbentuk bulat telur. Jumlah dinding spora yang terlihat sebanyak 2 lapisan. Permukaan spora berwarna bening dan setelah ditetesi larutan melzer tidak terjadi perubahan warna spora atau tetap berwarna bening. Karakteristik spora yang ditemukan memiliki kesamaan dengan karakter yang dijelaskan oleh INVAM (2017) yaitu genus Archaeospora memiliki bentuk bulat, elips dan bulat telur, warna spora bening dan tidak bereaksi terhadap larutan melzer yang diberikan, jumlah dinding 2 sampai 3 lapisan.

Genus Glomus yang ditemukan memiliki karakteristik spora berbentuk bulat, bulat telur dan oval. Jumlah dinding spora yang terlihat 2 sampai 3 lapisan. Permukaan spora berwarna merah, orange dan kuning, tidak terjadi reaksi perubahan warna pada permukaan spora ketika ditetesi larutan melzer. Menurut INVAM (2017) spora genus Glomus memiliki karakter spora berbentuk bulat, bulat telur, elips dan oval, spora berwarna merah, kuning dan orange tidak mengalami perubahan warna setelah ditetesi melzer dan jumlah lapisan dinding sebanyak 1 sampai 4 lapisan. 
Genus Paraglomus yang ditemukan umumnya memiliki karakteristik berbentuk bulat dan bulat telur. Jumlah dinding spora yang terlihat sebanyak 2 lapisan. Permukaan spora berwarna bening dan bening kekuningan, tidak terjadi reaksi perubahan warna pada spora ketika ditetesi larutan melzer. Ciri khas genus Paraglomus memiliki ornamen Globus pada permukaannya, ciri tersebut terlihat sepeti bulatan bulatan kecil yang menutupi permukaan spora. Menurut INVAM (2017) spora genus Paraglomus berbentuk bulat,bulat telur dan elips, permukaannya berwarna kuning dan bening, terdapat Globus dan tidak bereaksi dengan melzer dinding spora 1 sampai 3 lapisan.

Berdasarkan hasil penelitian keanekaragaman spora yang ditemukan di setiap jenis tanah berbeda-beda. Genus Glomus ditemukan di semua jenis tanah. Genus Paraglomus dan Acaulospora ditemukan di tanah aluvial dan PMK, sedangkan Archaeospora hanya ditemukan di tanah aluvial. Keanekaragaman spora jamur MVA diduga dipengaruhi oleh perbedaan kandungan organik dan derajat keasaman $(\mathrm{pH})$ pada setiap tanah. Berdasarkan hasil analisis tanah (Tabel 4.4) yang menginformasikan bahwa kandungan organik dan $\mathrm{pH}$ pada tiap jenis tanah yang diamati memiliki perbedaan. Hal ini sesuai dengan pernyataan Johnson-Green et al., (1995) dan Widyaningrum et al., (2016) yang menyatakan bahwa perbedaan jenis tanah merupakan faktor yang dapat mempengaruhi keanekaragaman jamur MVA.

Genus Archaeospora hanya ditemukan pada tanah aluvial. Hal ini diduga keberadaan genus tersebut di pengaruhi oleh kandungan $\mathrm{P}$ dan $\mathrm{N}$ pada tanah. berdasarkan hasil Tabel 4.4 tanah aluvial yang diamati memiliki $\mathrm{P}$ 67,65 ppm dan $\mathrm{N}$ 0,64\%. Berdasarkan kriteria penilaian sifat tanah oleh Pusat Penelitian Bogor, (1983) dalam Lestari (2008) kondisi $\mathrm{P}$ dan $\mathrm{N}$ pada tanah aluvial di lokasi penelitian termasuk kriteria sangat tinggi, hal tersebut menunjukkan bahwa tanah tersebut banyak mengandung $\mathrm{P}$ dan N. Hasil Penelitian Saputra et al., (2015) menemukan genus Archaeospora di rhizosfer tanaman pisang pada tanah aluvial yang memiliki kandungan $\mathrm{P} 35,70$ ppm dan N 0,28\%. Sianturi et al., (2015) melaporkan genus Archaeospora ditemukan pada tanah gambut yang memiliki P 171,60 ppm dan N $3,45 \%$. Berdasarkan uraian tersebut menunjukkan bahwa genus Archaeospora ditemukan pada kondisi tanah yang banyak mengandung $\mathrm{P}$ dan $\mathrm{N}$.

Tanah salin yang diamati berasal dari kawasan mangrove di Kecamatan Mempawah Timur. Tanah salin tersebut memiliki $\mathrm{pH} \quad 5,58$ dan salinitas 1,6 ppt. Tekstur tanah tersebut liat berdebu dan memiliki sedikit pasir (Tabel 4.4). Rendahnya $\mathrm{pH}$ yang dimiliki oleh tanah salin dikarenakan tanah tersebut memiliki tanah liat bersifat masam. Hardjowigeno (1986) dalam Rachmawati (2012) salah satu ciri tanah mangrove ialah memiliki tanah liat yang bersifat masam, tanah masam mengandung sejumlah sulfat. Selain itu juga tanah salin di lokasi penelitian dipengaruhi oleh pasokan air tawar sehingga dapat menurunkan kadar garam dan menambah pasokan unsur hara. Sesuai dengan pernyataan Tomlison (1986) dalam Rachmawati (2012) kawasan mangrove dipengaruhi air tawar yang berasal dari sungai, air tawar dapat membantu menurunkan salinitas dan memberikan unsur hara.

Genus Archaeospora, Acaulospora dan Paraglomus tidak ditemukan pada tanah salin. Salinitas yang terkandung pada tanah tersebut diduga berpengaruh terhadap pertumbuhan dan perkembangan dari jamur MVA, karena hanya beberapa jenis jamur MVA yang dapat beradaptasi dengan salinitas. Hal tersebut sesuai dengan pernyataan D'souza \& Rodrigues (2013) yang mengatakan bahwa hanya jenis jamur MVA tertentu yang dapat tumbuh dan berkembang pada kondisi salin. Hasil penelitian ini didukung beberapa penelitian Rahmawati et al., (2013) dan Wanda et al., (2015) yang tidak menemukan genus Archaeospora, Acaulospora dan Paraglomus di tanah salin.

Genus Glomus merupakan genus yang mempunyai kemampuan adaptasi untuk hidup pada berbagai jenis tanah. Hal tersebut dapat lihat dari Tabel 4.3 yang menunjukkan bahwa genus Glomus ditemukan di tanah aluvial, salin dan PMK. Kemampuan genus Glomus diduga dikarenakan kemampuannya untuk beradaptasi dengan lingkungan dan mudah bersimbiosis dengan semua tumbuhan. Hal serupa juga ditunjukkan oleh Yurisman et al., (2015) menginformasikan bahwa genus Glomus lebih banyak ditemukan dibandingkan genus lainnya pada tanah aluvial. Natalia et al., (2016) yang melaporkan bahwa genus Glomus banyak ditemukan dan mampu beradaptasi dengan kondisi tanah salin. Hasil penelitian Saputra et al., (2015) pada tanah PMK menemukan spora genus Glomus dan jumlahnya mendominasi pada lokasi tersebut. Kehadiran genus Glomus yang ditemukan pada tiga lokasi penelitian juga berkaitan dengan tekstur tanah. Tekstur tanah pada tiga lokasi penelitian liat, berdebu dan berpasir (Tabel 4.4). Tekstur tanah tersebut merupakan kondisi yang cocok dengan petumbuhan dan perkembangan genus Glomus. 
Cahyani et al., (2014) mengungkapkan bahwa kondisi didominasi fraksi liat merupakan kondisi yang sesuai untuk pertumbuhan dan perkembangan genus Glomus.

Berdasarkan Tabel 2 terlihat pada tanah aluvial memiliki jumlah spora yang lebih rendah dibandingkan dengan jumlah spora pada tanah salin dan tanah PMK. Hal tersebut diduga dikarenakan tingginya kandungan organik atau unsur hara pada tanah tersebut (Tabel 4.4). Diketahui tingginya unsur hara N, P, K pada suatu tanah akan menyebabkan tertekannya pertumbuhan dan perkembangan jamur MVA, karena tumbuhan tidak memerlukan jamur MVA untuk membantunya dalam menyerap air dan unsur hara. Sehingga jamur MVA tidak mendapatkan karbohidrat yang berasal dari tumbuhan inang sebagai sumber energi. Hayman (1975) dalam Astuti (2000), Sumiati dan Gunawan (2006), menyebutkan bahwa kandungan $\mathrm{N}, \mathrm{P}, \mathrm{K}$ yang tinggi pada tanah dapat menurunkan jumlah spora. Hal tersebut disebabkan menurunnya daya perkecambahan spora jamur MVA.

Infeksi jamur MVA ditandai oleh adanya vesikula dan hifa pada jaringan akar. Berdasarkan hasil perhitungan tingkat infeksi akar menunjukkan bahwa tumbuhan lakum yang hidup pada tanah salin dan tumbuhan lakum yang ditemukan tanah PMK memiliki tingkat infeksi akar dengan kategrori tinggi, sedangkan pada tanah aluvial tingkat infeksi berkategori rendah. Tingkat infeksi jamur MVA pada inang berkaitan erat dengan kandungan $\mathrm{P}$ (phosfor) pada tanah tersebut. Berdasarkan hasil analisis tanah dapat dilihat bahwa kandungan $\mathrm{P}$ tanah PMK dan tanah salin lebih rendah dari kandungan $\mathrm{P}$ yang ada pada tanah aluvial (Tabel 4.4). Hal tersebut menunjukkan bahwa kandungan $\mathrm{P}$ yang rendah mendukung adanya infeksi atau kolonisasi jamur MVA pada jaringan akar. Kandungan $\mathrm{P}$ yang rendah dapat merangsang tumbuhan inang dan jamur MVA bersimbiosis. Selain itu Kandungan $P$ yang rendah dapat membantu mempercepat pertumbuhan hifa dari spora yang berkecambah (Kowalska et al., 2015). Hasil yang sama ditunjukkan pada penelitian Dewi (2014), Yualinitha et al., (2012) yang melaporkan bahwa tumbuhan yang hidup pada kondisi tanah yang memiliki kandungan $\mathrm{P}$ rendah memiliki infeksi akar yang lebih tinggi dibandingkan infeksi akar pada tumbuhan yang hidup pada kondisi tanah yang mengandung $\mathrm{P}$ tinggi.
Selain pengaruh kandungan $\mathrm{P}$ yang rendah, tingginya infeksi jamur MVA pada akar tumbuhan lakum yang hidup di tanah salin dan PMK dipengaruhi juga oleh tekstur tanah salin dan PMK yang memiliki fraksi liat. Tektur tanah PMK yang liat apabila dalam kondisi kering atau lembab struktur tanahnya akan menjadi rapat. Kondisi tersebut akan mengakibatkan akar sulit menembus pori-pori tanah, sehingga membutuhkan jamur MVA untuk membantu menyerab unsur hara dan air yang dibutuhkan oleh tumbuhan. Sesuai dengan pernyataan Sieverding et al., (1996) dalam Yusra (2005) tanah yang memiliki fraksi liat dan rapat dalam kondisi kering atau lembab akan menyulitkan akar tumbuhan menyerap unsur hara dan air.

\section{DAFTAR PUSTAKA}

Astuti, W, D, 2000, Biodiversitas Cendawan Mikoriza Arbuskula Pada Rizosfer Rumput Gajah (Pennisetum purpureum) di Bogor dan Lembang, Skripsi, Jurusan Ilmu Nutrisi dan Makanan Ternak, Fakultas Peternakan, Intitut Pertanian Bogor

Ayyanar, M, \& Lgnacimuthu, S. Plants Used For NonMedicinal Purposes By The Tribal People In Kalakad, Mundan-Thurai Tiger, Reserve Southern India. Indian J Tradit Knowl, vol. 9

Cahyani, Ni, Kadek, M, D, Nurhatika, S, Muhibuddin, 2014, Eksplorasi Mikoriza Vesikular (MVA) Indigenous pada Tanah Aluvial di Kabupaten Pamekasan Madura, vol. 3, no. 1, hal 2337-3520

Choudhary, K, Singh, M, \& Pillai, U, 2007, 'Ethnobotanical Survey of Rajasthan - An Update', American-Eurasian Journal of Botany, vol.1, no.2, hal.38-45.

D'Souza, J, dan Rodrigues, B.F, 2013, Biodiversity of Arbuscular Mycorizal (AM) Fungi in Mangrove of Goa in West India, Jur of Forestry Research, vo. 24, no. 3, hal 515-523

Dewi, Agustina, P, 2014, Keanekaragaman Fungi Mikoriza Arbuskula di Bawah Tegakan Jabon (Anthocephalus cadamba) di Madiun, Jawa Timur, Skripsi, Departemen Silvikultur, Fakultas Kehutanan, Institut Pertanian Bogor

INVAM, 2017, International Culture Collection of (Vesicular) Arbuscular Mycorrhizal Fungi, diakses 14 oktober 2017, $<$ http://invam.wvu.edu/the-fungi/speciesdescriptions $>$

Johnson-Green PC, Kenkel N,C, Booth, T. 1995, The Distribution and Phenologhy of arbuscular mycorrhhizae along an inland salinity gradient. Can. J. Bot.vol 73. hal 1318-1327

Kaleka, N, 2013, Pisang-Pisang Komersial, Pustaka Baru, Yogyakarta 
Kartika, E, 2001, 'Isolasi, Karakterisasi \& Pengujian Keefektifan Cendawan Mikoriza Arbuskular Terhadap Bibit Kelapa Sawit Pada Tanah Gambut Bekas Hutan', Jurnal Agronomi, vol. 10, no. 2, hal. 63-70, diakses tanggal 15Oktober2017,

<http://download.portalgaruda.org/article.php? article $=11918 \& \mathrm{val}=876>$

Kowalska, I, Konieczny, A, Gastol, M, Wtodzimier, S, Hanus-Fajerska, E, 2015, Effect of Mycorrhiza and phosphorus content in nutrient solution on the yield and nutritional status of tomato plant grown on rockwool or coconut coir, $J$. Agricultural and food science, vol 24, hal 39-51

Kristiono, A, Purwaningrahayu, R,D, Taufiq, A, 2013, Respon Tanaman Kedelai, Kacang Tanah dan Kacang Hijau terhadap Cekaman Salinitas, Buletin Palawija, no. 26

Kumar, D, Kumar, S, Gupta, J, Arya, R, Gupta, A, 2011, 'A review on chemical and biological properties of Cayratia trifolia Linn. (Vitaceae)', Pharmacognosy Reviews, vol. 5, issue 10, 1848, DOI: 10.4103/0973-7847.91117, diakses tanggal $20 \quad$ Oktober 2017, https://www.scienceopen.com/document/review s/vid/c41ca156-18fa-4af8-87b2828760b1f9ab;jsessionid=nqjLbjH6mUhE7iEV ZINaR2ZW.master:so-app1-prd?0

Lestari CT, 2008, Keanekaragaman Jamur Mikoriza Vesikular Arbuskular (MVA) Pada Areal Tanaman Jagung (Zea mays L.) yang Diaplikasikan Herbisida Paraquat di Dusun Sujah Kecamatan Seluas Kabupaten Bengkayang, Skripsi, Universitas Tanjungpura, Pontianak

Natalia, N, Riniarti, M, Rini, M, V, 2016, Eksplorasi Fungi Mikoriza Arbuskula (PMA) di Hutan Pendidikan Mangrove UNILA Desa Margasari, Kabupaten Lampung Timur, Seminar Nasional Perikanan dan Kelautan 2016.

Prasetyo, B, Linda, R, Mukarlina, 2016, Pemanfaatan Tumbuhan Lakum (Cayratia trifolia (L) Domin) Oleh Etnis Melayu di Kecamatan Sungai Kunyit, Kabupaten Mempawah, vol. 5, no. 2, hal 25-33

Putri, N,N,T,A,N, 2015, Pengaruh Peningkatan Konsentrasi Ekstrak Daun Galing-Galing (Cayratia trifolia L) Terhadap Stabilitas Busa Dan Daya Bersih Pada Sediaan Sampo Veteriner, Skripsi, Fakultas Matematika dan Ilmu Pengetahuan Alam, Universitas Udayana

Rachmawati, 2012, Hubungan Sifat Tanah dengan Tipe Vegetasi Mangrove di Desa Blanakan, Kabupaten Subang, Skripsi, Departemen Ilmu
Tanah dan Sumberdaya Lahan, Fakultas Pertanian, Intitut Pertanian Bogor.

Saputra, B, Linda, R, Lovadi, I, 2015, Jamur Mikoriza Vesikular Arbuskular (MVA) pada Tiga Jenis Tanah Rhizosfer Tanaman Pisang Nipah (Musa paradisiaca L. var. nipah) Di Kabupaten Pontianak, vol. 4, no. 1, hal 160-169

Schenck, NC \& Perez Y, 1990, Manual for Identification of VA Mycorhizal Fungi, Synergistic Publication, USA

Sianturi, F, Linda, R, Khotimah, S, 2015, Kepadatan Spora Jamur Mikoriza Vesikular Arbuskular Pada Tiga Tingkat Kematangan Gambut Di Kawasan Hutan Lindung Gunung Ambawang Kabupaten Kubu Raya, $J$. Protobiont, vol 4, no. 2, hal 96-102

Sumiati, E, dan Gunawan, O, S, 2006, Aplikasi Pupuk Hayati Mikoriza untuk Meningkatkan Efisiensi Serapan Unsur Hara NPK serta Pengaruhnya terhadap Hasil dan Kualitas Umbi Bawang Merah, J. Hort, Vol.17, No.1, Hal 34-42

Triningsih, A, 2008, Keanekaragaman Jenis Jamur Mikoriza Vesikular Arbuskular Pada Tanaman Lidah Buaya (Aloe vera L.) Di lahan Gambut Kecamatan Pontianak Utara, Skripsi, Universitas Tanjungpura, Pontianak

Yurisman, B, Burhanuddin, Wahdina, 2015, Asosiasi Fungi Mikoriza Arbuskula (FMA) Pada Tanaman Bintaro (Cerbera manghas Linn.) di Tanah Aluvial, Jurnal Hutan Lestari, vol. 3, no. 4 , hal 551-560

Yusra, 2005, 'Pengaruh Lateks \& Cendawan Mikoriza Terhadap P-Total, P-Tersedia, \& pH Tanah Ultisol', Jurnal Ilmiah Pertanian Kultura, vol. 40, no. 2, hal. 100- 105, diakses tanggal 11 Agustus 2014 , <http://repository.usu.ac.id/bitstream/12345678 9/19928/1/Yusra\%3B\%20Pengaruh\%20Lateks $\%$ 20dan\%20Cendawan\%20Mikoriza\%20terhad ap\%20P-Total,\%20P-

Tersedia\%20dan\%20pH\%20Tanah\%20Ultisols. pdf>

Widyaningrum, N, Rakhmawati, A, Aminatun, T, 2016, Eksplorasi Mikoriza Vesikular Arbuskular (MVA) Rizosfer Gulma Siam (Chromolaena odorata) (L.) R.M King and H. Robinson, Jurnal Biologi, vol. 5, no.8, hal 28-37

Wanda, A,R, Yuliani, Trimulyono,G, 2015, Keanekaragaman Cendawan Mikoriza Vesikular Arbuskular (MVA) di Hutan Pantai Nepa Sampang Madura Berdasarkan Gradien Salinitas, LenteraBio, vol. 4, no. 3, hal. 180186 